\title{
Writing the
}

Wrongs

\section{Eva Valesh and the Rise of Labor Fournalism}

G

\section{ELIZABETH FAUE}

Cornell University Press 
Copyright $(\mathcal{C} 2002$ by Cornell University

All rights reserved. Except for brief quotations in a review, this book, or parts thereof, must not be reproduced in any form without permission in writing from the publisher. For information, address Cornell University Press, Sage House, 5 I2 East State Street, Ithaca, New York 1485 o.

First published 2002 by Cornell University Press

Printed in the United States of America

Library of Congress Cataloging-in-Publication Data

Faue, Elizabeth.

Writing the wrongs : Eva Valesh and the rise of labor journalism/

Elizabeth Faue.

p. $\mathrm{cm}$.

Includes bibliographical references and index.

ISBN 978-0-8014-8465-0

I. Valesh, Eva McDonald, I866-1956. 2. Journalists-United States-

Biography. 3. Labor journalism-United States. I. Title.

$\mathrm{PN}_{4} 874 . \mathrm{V}_{25} \mathrm{~F}_{3} 82002$

$070^{\prime} .9233 \mathrm{I}^{\prime} 092-\mathrm{dc2}$

2001006507

Cornell University Press strives to use environmentally responsible suppliers and materials to the fullest extent possible in the publishing of its books. Such materials include vegetable-based, low-VOC inks and acid-free papers that are recycled, totally chlorine-free, or partly composed of nonwood fibers. For further information, visit our website at www.cornellpress.cornell.edu.

Cloth printing 10 987654321 
in memory of my mother, Yvonne, whose gift of memory I share, and for my father, Vincent, who taught me about Fobn Wayne movies, war stories, and the difference between the two

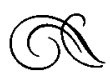


This page intentionally left blank 